\title{
Pelaksanaan Discharge Planning pada Pasien Hipertensi di RSUD Panembahan Senopati Bantul
}

\author{
Sugino', Fatma Siti Fatimah', R Agus Siswanto' \\ Ilmu Keperawatan, Univeristas Alma Ata, Yogyakarta, Indonesia \\ Email: fatmasitifatimah@almaata.ac.id
}

\begin{abstract}
Abstrak
Hipertensi merupakan penyakit tidak menular yang masih menjadi masalah dibidang kesehatan. Upaya penanganan hipertensi pada dasarnya sudah dijalankan dengan berbagai cara termasuk kegiatan untuk meningkatkan pengetahuan penderita hipertensi. Pengetahuan dapat ditingkatkan melalui komunikasi informasi edukasi. Salah satu yang biasanya dilakukan petugas kesehatan ditatanan pelayanan kesehatan adalah pelaksanaan discharge planing. discharge planning adalah perencanaan pulang, sejak pasien masuk rumah sakit sampai pasien pulang yang dilakukan oleh petugas Kesehatan. Penelitian ini merupakan penelitian deskriptif dengan pendekatan retrospektif. Populasi penelitian ini adalah rekam medis pasien hipertensi yang mendapatkan rawat inap dan dinyatakan pulang dari bulan Agustus sampai dengan bulan Oktober 2017. Besarnya sampel penelitian sebanyak 145 rekam medis. Besarnya sampel tiap bangsal menggunakan rumus sampling fraction cluster. Instrumen penelitian menggunakan lembar checklist pemberian Pendidikan kesehatan. Analisa data menggunakan deskriptif statistik. Hasil dan Kesimpulan: Hasil penelitian menunjukan program pendidikan kesehatan secara keseluruhan 145 (100\%) dilaksanakan, sebagian besar menggunakan metode diskusi 145 (100\%), respon pasien atau keluarga pasien hipertensi setelah diberi pendidikan kesehatan sebagian besar paham tapi tidak bisa menjelaskan sendiri $113(77,93 \%)$, pemberi pendidikan kesehatan sebagian besar dilaksanakan oleh dokter 135 (93,10\%), dan penerima pendidikan kesehatan terbanyak diterima oleh keluarga pasien hipertensi 122 (84,14\%).
\end{abstract}

Kata Kunci: Discharge Planning, Hipertensi

\section{Discharge Planning Implementation in Patients Hypertension In RSUD Panembahan Senopati Bantul Abstract}

Hypertension is a non-communicable disease that is still a problem in the field of health. Hypertension treatment efforts have basically been executed in various ways including activities to increase knowledge of hypertensive patients. Knowledge can be improved through education information communication. One of the most commonly performed health workers on health services is the implementation of discharge planing. discharge planning is planning to go home, from hospital admission until the patient is discharged by a health worker. Research Method: This research is a descriptive research with retrospective approach. The population in this study is the medical records of hypertensive patients who received hospitalization and was declared to return from August to October 2017. The amount of research sample counted 145 medical record of hypertension patient by using slovin formula. The sample size of each ward uses the fraction cluster sampling formula. The research instrument uses a health education checklist. Data analysis using descriptive statistics. Results and Conclusions: The results show that the overall health education program 145 (100\%) was conducted, mostly using the 145 (100\%) discussion method, the patient's or family's response to hypertension after being given a health education largely understood but unable to explain itself 113 (77.93\%), most health education providers were implemented by doctors 135 (93.10\%), and most health education recipients were received by families of hypertensive patients 122 (84.14\%).

Keywords: Discharge Planning, Hypertension

Received: 1/03/2019; published: 1/05/2019

Indonesian Journal of Hospital Administration Vol. 2 No. 1 


\section{PENDAHULUAN}

Hipertensi merupakan salah satu penyakit tidak menular yang masih menjadi masalah dibidang kesehatan yang sering ditemukan pada pelayanan kesehatan. Hipertensi dapat terjadi ketika adanya peningkatan tekanan darah sistolik lebih dari $140 \mathrm{mmHg}$ dan tekanan darah diastolik lebih dari $90 \mathrm{mmHg}(1)$. Hipertensi timbul sebagai akibat adanya interaksi berbagai faktor resiko yang dimiliki seseorang. Faktor resiko terjadinya hipertensi dapat dibedakan menjadi 2 yaitu faktor yang tidak dapat dikontrol seperti keturunan atau riwayat keluarga, jenis kelamin, dan umur, Sedangkan faktor yang dapat dikontrol seperti obesitas atau kegemukan, kurang olah raga, perilaku merokok dan pola konsumsi alkohol dan makanan yang mengandung natrium (2).

Sebanyak 1 milyar orang di dunia atau 1 dari 4 orang dewasa meninggal dengan penyakit ini. Bahkan diperkirakan jumlah penderita hipertensi akan meningkat menjadi 1,6 milyar menjelang tahun 2025 (2). Berdasarkan data dari World Health Organization (WHO) Tahun 2013 diketahui bahwa hipertensi sering menimbulkan penyakit kardiovaskular, ginjal dan stroke. sekitar 9,4 juta orang dari 1 milyar orang di dunia yang meninggal diakibatkan karena gangguan kardiovaskular. Prevalensi hipertensi di Negara maju maupun Negara berkembang masih tergolong tinggi, adapun prevalensi di Negara maju adalah sebesar 35\% dari populasi dewasa dan prevalensi hipertensi di Negara berkembang sebesar $40 \%$ dari populasi dewasa. sedangkan prevalensi hipertensi yang tertinggi terdapat di Afrika, yaitu sebesar $46 \%$ dari populasi dewasa (3).

Profil data kesehatan Indonesia tahun 2011 menyebutkan bahwa hipertensi merupakan salah satu dari 10 besar penyakit pasien rawat inap di rumah sakit pada tahun 2010, dengan proporsi kasus menurut jenis kelamin sebesar 43,42\% laki-laki dan 56,58\% perempuan (4). Sedangkan menurut data Riset kesehatan dasar (Riskesdas) pada tahun 2013 prevalensi hipertensi di indonesia pada umur $\geq 18$ tahun yang didapat melalui jawaban pernah didiagnosis oleh tenaga kesehatan sebesar 9,4\%, sedangkan yang pernah didiagnosis tenaga kesehatan atau sedang minum obat hipertensi sebesar 9,5\%. Jadi, terdapat $0,1 \%$ penduduk indonesia yang minum obat sendiri atau tidak menjalani pengobatan sesuai anjuran tenaga kesehatan meskipun tidak pernah didiagnosis hipertensi oleh tenaga kesehatan (5). Sedangkan untuk provinsi DI Yogyakarta prevalensi hipertensi pada umur $\geq 18$ tahun berdasarkan wawancara pada tahun 2013 yang pernah didiagnosis oleh tenaga kesehatan dan minum obat hipertensi sebesar 12,9\% (6). Menurut sistem informasi rumah sakit (SIRS) tahun 2015 jumlah kasus hipertensi yang rawat inap di rumah sakit lebih banyak pada perempuan yaitu sebanyak 39.823 kasus bila dibandingkan dengan laki- laki sebanyak 29.725 kasus. Sedangkan berdasarkan kelompok umur, kasus 
hipertensi yang rawat inap di rumah sakit terbanyak pada kelompok umur 45-64 tahun yaitu sebanyak

37.341 kasus (7).

Berdasarkan penelitian yang dilakukan wahyuningsih (2013) terhadap responden yang berusia $\geq 60$ tahun menyatakan bahwa dari 73 responden yang mengalami hipertensi sebanyak 35 responden (47,94\%) dan 38 responden (52,06\%) tidak mengalami hipertensi (8). Komplikasi hipertensi yang paling sering terjadi yaitu gagal jantung, stroke, gagal ginjal dan retinopati atau penyakit mata yang mengakibatkan kebutaan (2). Menurut penelitian yang dilakukan Hesty (2012) menyatakan bahwa dari 29 responden didapatkan lebih dari 50\% yang mengalami kejadian komplikasi hipertensi yaitu sebanyak 18 responden (62\%) dan 11 responden (38\%) tidak mengalami komplikasi hipertensi (9). Pengobatan hipertensi secara garis besar terdiri dari terapi farmakologis dan non farmakologi. Terapi farmokologis yaitu pengobatan dengan obat-obatan anti hipertensi sedangkan terapi non farmakologis dapat dilakukan dengan cara menurunkan berat badan berlebih, olah raga, mengurangi asupan garam, berhenti merokok dan tidak mengkonsumsi alkohol, dan hindari stres (2). Berbagai upaya penanganan hipertensi pada dasarnya sudah dijalankan dengan berbagai cara termasuk kegiatan untuk meningkatkan pengetahuan penderita hipertensi. Pengetahuan dapat ditingkatkan melalui KIE (Komunikasi Informasi Edukasi ), konseling, pendidikan kesehatan, promosi kesehatan, serta discharge planning (10). Pemberian discharge planning dapat meningkatkan kemajuan pasien dan membantu pasien untuk mencapai kualitas hidup optimum sebelum dipulangkan serta memberikan efek yang penting dalam menurunkan angka mortalitas dan morbiditas (11).

Discharge planing merupakan proses dimana mulainya pasien mendapatkan pelayanan kesehatan yang diikuti dengan kesinambungan perawatan baik dalam proses penyembuhan maupun mempertahankan derajat kesehatannya sampai pasien merasa siap untuk kembali ke lingkungannya. Perawat adalah salah satu anggota team discharge planner, sebagai discharge planner perawat mengkaji setiap pasien dengan mengumpulkan data yang berhubungan untuk mengidentifikasi masalah, menentukan tujuan dengan atau bersama pasien dan keluarga, memberikan tindakan khusus untuk mengajarkan atau memulihkan kembali kondisi pasien secara optimal (11). Perawatan di rumah sakit akan bermakna jika dilanjutkan dengan perawatan di rumah. Namun sampai saat ini perencanaan pulang bagi pasien yang dirawat belum optimal karena peran perawat masih terbatas pada pelaksanaan kegiatan rutinitas saja, yaitu hanya berupa informasi tentang jadwal kontrol ulang (10).

Tujuan perawat memberikan discharge planning adalah mempersiapkan klien dan keluarga baik secara fisik maupun psikologis untuk pulang ke rumah dengan memberikan Indonesian Journal of Hospital Administration Vol. 2 No.1 
pendidikan kesehatan kepada klien dan keluarga untuk memenuhi kebutuhan mereka dalam proses pemulangan (12). Di Indonesia semua pelayanan keperawatan rumah sakit telah merancang berbagai bentuk format dicharge planning, akan tetapi discharge planning kebanyakan dipakai hanya dalam bentuk pendokumentasian resume pasien pulang, berupa informasi yang harus disampaikan pada pasien yang akan pulang seperti intervensi medis dan non medis yang sudah diberikan, jadwal kontrol, gizi yang harus dipenuhi setelah di rumah. cara ini merupakan pemberian informasi yang sasarannya ke pasien dan keluarga hanya untuk mengingatkan pengetahuan, namun tidak ada yang bisa menjamin apakah pasien dan keluarga mengetahui faktor resiko apa yang dapat membuat kambuh, penanganan apa yang harus dilakukan bila terjadi kegawatdaruratan terhadap kondisi penyakitnya, untuk itu pelaksanaan discharge planning di rumah sakit sangat penting apalagi dengan penyakit kronis yang memiliki resiko untuk kambuh dan berulangnya kegawatan dimana akan memberikan proses deep- learning pada pasien hingga terjadinya perubahan perilaku pasien dan keluarganya dalam memaknai kondisi kasehatannya (11). Hal ini sesuai dengan penelitian Pathimatuz Zuhra (2016) yang menyatakan bahwa pelaksanaan discharge planning di RS PKU Muhammadiyah Gamping Yogyakarta masih kurang optimal, sebagian besar tindakan discharge planning dilakukan pada hari pemulangan, serta perawat hanya melakukan bagian yang penting saja dalam pelaksanaan discharge planning tanpa memperhatikan detail dari tindakan discharge planning itu sendiri (13).

\section{BAHAN DAN METODE}

Jenis penelitian yang digunakan adalah penelitian deskriptif dengan pendekatan data menggunakan retrospektif yang dilaksanakan pada bulan Januari 2018 di Instalasi rekam medis RSUD Panembahan Senopati Bantul. Populasi dalam penelitian ini adalah rekam medis pasien hipertensi yang mendapatkan perawatan dan dinyatakan pulang dari bulan Agustus sampai dengan bulan Oktober 2017 dengan jumlah 227 pasien hipertensi dari 5 bangsal rawat inap. Besarnya sampel dalam penelitian ini sebanyak 145 rekam medis pasien hipertensi dengan menggunakan rumus slovin. Besarnya sampel tiap bangsal didapatkan dengan menggunakan rumus sampling fraction cluster dengan rincian sebagai berikut : ruang bakung sebanyak 51 , ruang cempaka sebanyak 36 , ruang flamboyan sebanyak 43, ruang mawar sebanyak 10 , dan ruang nusa indah sebanyak 5 pasien. Teknik undian untuk mendapatkan sampel penelitian tiap-tiap bangsal.

Variabel dalam penelitian ini adalah variabel tunggal yaitu pelaksanaan discharge planning pada pasien hipertensi. Instrumen yang digunakan dalam penelitian ini adalah dengan menggunakan lembar ceklist pemberian pendidikan kesehatan. Analisa data menggunakan statistik deskriptif yang disajikan dalam bentuk tabel distribusi frekuensi 


\section{HASIL DAN PEMBAHASAN}

Hasil penelitian ini ditampilkan pada Tabel 1 berikut:

Distribusi frekuensi program pendidikan kesehatan yang diberikan oleh petugas kesehatan pada pasien hipertensi di RSUD Panembahan Senopati $(n=145)$ dalam tabel berikut

Tabel 1 Distribusi frekuensi program pendidikan kesehatan yang diberikan oleh petugas kesehatan pada pasien hipertensi di RSUD Panembahan Senopati $(n=145)$

\begin{tabular}{lcc}
\hline $\begin{array}{c}\text { Program pendidikan } \\
\text { kesehatan }\end{array}$ & Frekuensi & (\%) \\
\hline Dilaksanakan & 145 & 100 \\
Tidak Dilaksanakan & 0 & 0 \\
Jumlah & $\mathbf{1 4 5}$ & $\mathbf{1 0 0}$ \\
& &
\end{tabular}

Berdasarkan Tabel 1 dapat diketahui bahwa pelaksanaan discarghe planning pada pasien hipertensi melalui pemberian pendidikan kesehatan yang diberikan oleh tenaga kesehatan didapatkan hasil 145 (100\%) dilaksanakan. Dari 145 pasien hipertensi yang rawat inap secara keseluruhan program pendidikan kesehatan sudah dilaksanakan oleh petugas kesehatan, meskipun dalam memberikan program pendidikan kesehatan masih ada salah satu item atau lebih program pendidikan kesehatan yang tidak diberikan kepada semua pasien hipertensi yang rawat inap. Disamping itu petugas juga telah memberikan pendidikan kesehatan kepada pasien hipertensi yang dirawat inap walaupun edukasi yang diberikan tidak terdapat dalam konsep program pendidikan kesehatan. Selain memberikan edukasi yang ada dalam program pendidikan kesehatan ada juga perawat yang memberikan discharge planning kepada pasien hipertensi yang dirawat inap yaitu sebanyak 5 pasien $(3,44 \%)$ dan telah memberikan semua item yang terdapat dalam program pendidikan kesehatan. Sebelum pasien pulang, perawat memberikan edukasi tentang obat yang harus dilanjutkan di rumah, jadwal kontrol dan perawatan diri atau perawatan lanjutan di rumah.

Program pendidikan Frekuensi (\%) Menurut Nursalam salah satu kesehatan komponen perencanaan pulang yaitu perawatan lanjutan dirumah. Penjelasan tentang perawatan dirumah baik kepada pasien maupun keluarga pasien sangat diperlukan karena akan berpengaruh terhadap kesehatan pasien, maka dari itu peran petugas kesehatan sangat dibutuhkan dalam proses pemberian pendidikan kesehatan (10). Pemberian pendidikan kepada pasien dan keluarga adalah suatu usaha atau kegiatan yang dilakukan dalam rangka memberikan informasi terhadap masalah kesehatan pasien yang belum diketahui oleh pasien dan keluarganya, sedangkan hal tersebut perlu diketahui untuk membantu atau mendukung penatalaksanaan medis dan atau tenaga kesehatan lainnya (17). 
Tabel 2 Distribusi frekuensi metode pemberian pendidikan kesehatan oleh petugas kesehatan pada pasien hipertensi yang rawat inap di RSUD Panembahan Senopati Bantul

\begin{tabular}{lcc}
\hline \multicolumn{1}{c}{$\begin{array}{c}\text { Metode Pendidikan } \\
\text { Kesehatan }\end{array}$} & Frekuensi & (\%) \\
\hline Diskusi & 145 & 100 \\
Peragaan & 1 & 0,68 \\
Selebaran & 27 & 18,62 \\
Audio Visual & 0 & 0 \\
\hline *Sumber: Data sekunder 2017 &
\end{tabular}

Berdasarkan Tabel 2 dapat diketahui bahwa metode yang digunakan oleh petugas kesehatan dalam memberikan pendidikan pada pasien hipertensi yang dirawat inap sebagian besar menggunakan metode diskusi yaitu sebanyak 145 (100\%), metode ini sering digunakan oleh Dokter, Perawat, Ahli gizi dan petugas Farmasi baik kepada pasien langsung maupun keluarga pasien. Selain menggunakan metode diskusi dalam memberikan pendidikan kesehatan Ahli gizi juga menggunakan metode selebaran. Menurut Notoatmodjo dalam proses pendidikan kesehatan terjadi pengaruh timbal balik antara berbagai faktor, antara lain: subyek belajar, pengajar, metode dan teknik belajar, alat bantu belajar dan materi atau bahan yang dipelajari. Sedangkan keluaran adalah hasil dari proses belajar, yaitu berupa kemampuan dan perubahan perilaku dari subyek belajar. Metode yang digunakan saat melakukan pendidikan kesehatan juga berpengaruh terhadap peningkatan pengetahuan (18).

Tabel 3 Distribusi frekuensi respon pasien atau keluarga pasien hipertensi yang idrawat inap setelah diberikan pendidikan kesehatan di RSUD Panembahan Senopati Bantul

\begin{tabular}{lcc}
\hline \multicolumn{1}{c}{ Respon pasien atau keluarga pasien } & Frekuensi & $(\%)$ \\
\hline Tidak direspon sama sekali & 0 & 0 \\
Tidak paham & 0 & 0 \\
Paham tapi tidak bisa menjelaskan sendiri & 113 & 77.93 \\
Dapat menjelaskan tapi dibantu educator & 32 & 22.06 \\
Dapat menjelaskan tanpa bantuan & 0 & 0 \\
Jumlah & 145 & 100 \\
\hline
\end{tabular}

*Sumber: Data sekunder 2017

Berdasarkan Tabel 3 dapat diketahui bahwa respon pasien atau keluarga pasien setelah diberikan pendidikan kesehatan sebagian besar respon paham tapi tidak bisa menjelaskan sendiri yaitu sebanyak 113 (77,93\%). Hal ini menunjukan bahwa respon pasien atau keluarga pasien setelah diberikan pendidikan kesehatan didominasi oleh respon paham tapi tidak bisa menjelaskan sendiri. Meskipun tidak bisa menjelaskan sendiri akan tetapi pasien atau keluarga pasien setelah diberikan pendidikan kesehatan dapat digambarkan bahwa telah terjadi perubahan terhadap pengetahuannya. Menurut Notoatmodjo 
pengetahuan merupakan hasil dari tahu mengenai suatu obyek tertentu setelah melalui panca indra manusia yaitu penglihatan, pendengaran, rasa dan perabaan (18).

Tabel 4 Distribusi frekuensi pemberi pendidikan kesehatan pada pasien hipertensi yang rawat inap di RSUD Panembahan Senopati Bantul

\begin{tabular}{lcc}
\hline \multicolumn{1}{c}{ Pemberi pendidikan keehatan } & Frekuensi & $\mathbf{( \% )}$ \\
\hline Dokter & 135 & 93,10 \\
Perawat & 92 & 63,44 \\
Ahli Gizi & 58 & 40 \\
Farmasi & 6 & 4,14 \\
\hline
\end{tabular}

*Sumber: Data sekunder 2017

Berdasarkan Tabel 4 dapat diketahui bahwa dari 145 pasien hipertensi yang rawat inap, pemberi pendidikan kesehatan sebagian besar dilakukan oleh dokter yaitu sebanyak 135 (93,10\%), sedangkan paling sedikit dilakukan oleh petugas farmasi yaitu sebanyak 6 $(4,14 \%)$. Hal ini menunjukan bahwa pemberi pendidikan kesehatan pada pasien hipertensi yang dirawat inap lebih didominasi oleh dokter. Setiap pemberi pelayanan kesehatan (edukator) yang melakukan edukasi atau memberikan pendidikan kesehatan wajib melakukan identifikasi pada form identifikasi kebutukan edukasi pada pasien dan atau keluarga pasien hipertensi.

Menurut Potter \& perry yang terpenting hasil yang diharapkan dalam edukasi kesehatan adalah terjadinya perubahan sikap dan perilaku individu, keluarga dan masyarakat untuk dapat menanamkan prinsip- prinsip hidup sehat dalam kehidupan sehari- hari demi mencapai derajat kesehatan yang optimal $(17,18)$.

Tabel 5 Distribusi frekuensi penerima pendidikan pada pasien hipertensi yang rawat inap di RSUD Panembahan Senopati Bantul

\begin{tabular}{lcc}
\hline $\begin{array}{c}\text { Penerima pendidikan } \\
\text { kesehatan }\end{array}$ & Frekuensi & (\%) \\
\hline Pasien & 23 & 15,86 \\
Keluarga pasien & 122 & 84,14 \\
Jumlah & 145 & 84,14 \\
\hline
\end{tabular}

*Sumber: Data sekunder 2017

Berdasarkan Tabel 5 dapat diketahui bahwa penerima pendidikan kesehatan paling banyak diterima oleh keluarga pasien hipertensi yaitu sebanyak 122 (84,14\%), sedangkan yang diterima oleh pasien hipertensi yaitu sebanyak 23 (15,86\%), hal ini menunjukan bahwa penerima pendidikan kesehatan lebih didominasi oleh keluarga pasien, apalagi jika kondisi pasien tidak memungkinkan untuk dilakukan edukasi maka peran keluarga sangat diperlukan dalam berpartisipasi untuk menerimapendidikan kesehatan demi kelangsungan hidup pasien. Indonesian Journal of Hospital Administration Vol. 2 No.1 
Menurut Friedman keluarga yang merupakan bagian dari masyarakat sesungguhnya mempunyai peranan penting dalam membentuk budaya dan perilaku sehat. Oleh karena itu, keluarga mempunyai posisi yang strategis untuk dijadikan sebagai unit pelayanan kesehatan karena masalah kesehatan dalam keluarga saling berkaitan dan saling mempengaruhi antar anggota keluarga, yang pada akhirnya juga akan mempengaruhi keluarga dan masyarakat yang ada disekitarnya (20).

\section{SIMPULAN DAN SARAN}

Program pendidikan kesehatan yang diberikan oleh petugas kesehatan pada pasien hipertensi yang dirawat inap 100\% dilaksanakan. Metode pemberian pendidikan kesehatan oleh petugas kesehatan pada pasien hipertensi yang rawat inap sebagian besar menggunakan metode diskusi yaitu sebanyak 145 (100\%). Respon pasien atau keluarga pasien hipertensi yang dirawat inap setelah diberi pendidikan kesehatan sebagian besar paham tapi tidak bisa menjelaskan sendiri yaitu sebanyak 113 (77,93\%). Pemberi pendidikan kesehatan pada pasien hipertensi yang dirawat inap sebagian besar dilaksanakan oleh Dokter yaitu sebanyak 135 (93,10\%). Penerima pendidikan kesehatan baik pasien hipertensi atau keluarga pasien hipertensi yang dirawat inap paling banyak diterima oleh keluarga pasien yaitu sebanyak $122(84,14 \%)$.

Peneliti selanjutnya sebaiknya melakukan penelitian tentang pelaksanaan discharge planning dengan menggunakan metode observasi agar lebih teridentifikasi sejauh mana pelaksanaannya, karena di RSUD Panembahan Senopati Bantul sebenarnya perawat telah melaksanakan discharge planning pada pasien namun pendokumentasiannya tidak tepat dikarenakan belum memiliki format khusus discharge planning.

\section{DAFTAR PUSTAKA}

1. Kementerian Kesehatan RI. Pusat data dan informasi. Mencegah dan mengontrol Hipertensi agar terhindar dari kerusakan organ jantung, otak dan ginjal. Kementerian Kesehatan RI; 2014.

2. Herlambang. Menaklukan Hipertensi dan Diabetes.Yogyakarta: Tugu Publisher.

3. 2013.

4. World Health Organization (WHO). World Health Day 2013: calls for intensified efforts to prevent and control hypertension. 2013. Di akses dari : http:// www.who.int > new> releases $>$ World. Health. Day. 2013. (diakses pada tanggal 16 November 2017).

5. Kementerian Kesehatan RI. Profil Data kesehatan Indonesia 2011. Jakarta: Kementerian Kesehatan RI; 2012 
6. Kementerian Kesehatan RI. Riset Kesehatan Dasar 2013. Jakarta: Kementerian Kesehatan RI; 2013

7. Kementerian Kesehatan RI. Profil Data Kesehatan Indonesia 2013. Jakarta: Kementerian Kesehatan RI; 2014.

8. Kementerian Kesehatan RI. Profil Penyakit Tidak Menular Tahun 2016. Jakarta: Kementerian Kesehatan RI; 2017.

9. Wahyuningsih \& Astuti. Faktor Yang Mempengaruhi Hipertensi Pada Usia Lanjut. JNKI, Volume 1,No.3 STIKES Alma Ata; 2013. Di akses dari http: // www.ejournal.almaata.ac.id. Pada tanggal 8 November 2017.

10. Hesti Titis Prasetyorini. Stress Pada Penyakit Terhadap Kejadian Komplikasi Hipertensi Pada Pasien Hipe rtensi. 2012.

11. Nursalam. Manajemen Keperawatan : Aplikasi dalam Praktik Keperawatan Profesional. Edisi 4. Jakarta : Salemba Medika. 2014.

12. Pemila, U (2010). Konsep Discharge Planning. Di akses dari http:// www.pkko.fik.ui.ac.id >files> konsep discharge planning.doc Pada tanggal 3 november 2017.

13. Nursalam dan Efendi F. Pendidikan dalam Keperawatan. Jakarta: Salemba Medika. 2008 Pathimatuz Zuhra. Gambaran pelaksanaan discharge planning pasien pascaoperasi Apendiktomi di RS PKU Muhammadiyah Gamping yogyakarta. 2016.

14. Ircham Machfoedz. Metodologi Penelitian Kuantitatif \& Kualitatif Bidang Kesehatan, Keperawatan, Kebidanan, Kedokteran. Edisi Revisi. Yogyakarta:Fitramaya; 2016.

15. Notoatmodjo, S. Metodologi Penelitian Kesehatan. Jakarta: Rineka Cipta. 2010.

16. Sugiyono. Metode Penelitian Kuantitatif, Kualitatif, dan R\&D. Bandung: Alfabeta. 2017.

17. Potter, P. A., \& Perry, A. G. Fundamental Keperawatan, Edisi 7. Jakarta : Salemba Medika. 2009.

18. Setiyani Y, Fatimah FS, Sumarsi S. Hubungan Pemberian Discharge Planning dengan Kecemasan pada Pasien Diabetes Melitus. Indonesian Journal of Hospital Administration. 2019 Oct 18;1(2):89-96.

19. Notoatmodjo, S. Promosi Kesehatan dan IImu Perilaku. Jakarta: Rineka Cipta. 2007

20. Friedman, Marlyn M. buku Ajar Keperawatan Keluarga : Riset, Teori dan Praktek. Jakarta : EGC. 2010 